\author{
Marzena Hajduk-Stelmachowicz \\ Politechnika Rzeszowska im. Ignacego Łukasiewicza, Polska - Ignacy Łukasiewicz Rzeszow University \\ of Technology, Poland
}

\title{
Promocja szkoły w środowisku jako kompetencja kierownicza w zakresie organizacji i zarządzania oświatą
}

\section{Promotion of School as a Managerial Competence in the Organisation and Management of Education}

Streszczenie: Celem niniejszego artykułu jest prezentacja znaczenia promocji szkoły w środowisku jako ważnej kompetencji dyrektorów (szczególnie tych podejmujących pracę po raz pierwszy). W związku $\mathrm{z}$ powyższym podjęto się $\mathrm{w}$ nim przedstawienia istoty promocji jako procesu. Wskazano cele promocji szkoły oraz dokonano typologizacji odbiorców działań promocyjnych. Zaprezentowano wybrane narzędzia promocji, które mogą być skutecznie używane przez osoby odpowiedzialne za organizację i zarządzanie placówką oświatową. Ponadto uporządkowano i wskazano instrumenty komunikacji marketingowej możliwe do wykorzystania podczas konstruowania tzw. planów promocji szkoły. Dla realizacji celu pracy dokonano analizy literatury. Zastosowano badanie typu desk research, metodę case study oraz benchmarking. Ustalono, że właściwie prowadzona promocja szkoły w środowisku powinna być dynamicznym procesem opartym na pętli podwójnego uczenia się. Oddziałuje ona bowiem na różne grupy interesariuszy na zasadzie sprzężenia zwrotnego. W pracy przyjęto następującą hipotezę badawczą: z perspektywy zarządzających promocja powinna stanowić sekwencję działań systemowych (na realizację których zapewnione są odpowiednie zasoby), celowych i zaplanowanych, opartych na odpowiednio dobranych metodach i formach skierowanych do zdefiniowanych odbiorców (zarówno do klientów wewnętrznych, jak i zewnętrznych).

\begin{abstract}
The aim of this article is to present the meaning of the promotion of school in the environment as an important competence of principals (especially those who take up the job for the first time). In connection with the above, an attempt was made to capture the essence of promotion as a process. The objectives of the promotion of the school were set and the typology of the recipients of the promotional activities was defined. The selected tools for the promotion, which can be used effectively by those responsible for the organisation and management of an educational institution, were presented. On top of this, the instruments of the marketing communication, which could be used during the preparation of the so-called school promotion plans were put in order and determined. In order to accomplish the aim of this paper, a decision was taken to analyse the literature. For this purpose, desk research, case study method and benchmarking were used. It was found that the proper promotion of the school in the environment should be a dynamic process based on the double-loop learning. It affects various groups of stakeholders, acting as feedback. From the perspective of the managers, promotion should constitute
\end{abstract}


a sequence of activities (with appropriate resources ensured to perform them), which are systemic, targeted and planned, based on appropriately selected methods and forms, addressed to defined recipients (both internal and external customers).

Słowa kluczowe: organizacja i zarządzanie oświatą; promocja; przedsiębiorczość; szkoła

Key words: organisation and management of education; promotion; school

Otrzymano: 27 października 2018

Received: 27 October 2018

Zaakceptowano: 11 lutego 2019

Accepted: 11 February 2019

\section{Sugerowana cytacja/Suggested citation:}

Hajduk-Stelmachowicz, M. (2019). Promocja szkoły w środowisku jako kompetencja kierownicza w zakresie organizacji i zarządzania oświatą. Przedsiębiorczość - Edukacja [Entrepreneurship Education], 15(1), 88-99. doi: 10.24917/20833296.151.7

\section{Wstęp}

O rosnącym znaczeniu promocji (w kontekście realizacji założeń zarządzania nie tylko operacyjnego, ale także strategicznego) przekonuje m.in. M. Bartnik, który zauważa, że: „Czy nam się to podoba, czy nie, trzeba informować klientów o swoich produktach, nieustannie szukać nowych, potencjalnych nabywców i nowych dróg dotarcia do nich. Trzeba podjąć aktywną komunikację z rynkiem [...]. Musimy cały czas robić hałas wokół naszych produktów, hałas wokół naszych usług [...]. Rynek musi cały czas o nas słyszeć! Musi słyszeć o tym, że rozszerzamy swoją działalność [...], że osiągnęliśmy rynkowy sukces..." (Bartnik, 2007: 7-8).

Z perspektywy rodziców oraz ich pociech konkurencja pomiędzy szkołami jest zjawiskiem pożądanym, gdyż pozytywnie wpływa na wzrost jakości usług edukacyjnych oferowanych przez konkretną szkołę. Należy mieć bowiem świadomość skracania się cykli życia poszczególnych typów usług edukacyjnych. W związku z tym można postawić tezę, iż najlepsze szkoły z wyprzedzeniem poszukują kolejnych, wysokiej jakości usług dodatkowych, odpowiadających na ciągle zmieniające się potrzeby rodziców. To właśnie takie szkoły mają szansę uzyskać miano szkół sukcesu.

W świetle budzących wiele dyskusji reform systemu edukacji dalsze funkcjonowanie części placówek szkolnych (z różnych przyczyn) stoi pod przysłowiowym znakiem zapytania. Celem niniejszego artykułu jest wskazanie znaczenia promocji szkoły w środowisku jako ważnej kompetencji osób na kierowniczych stanowiskach, tj. dyrektorów podejmujących pracę w zakresie organizacji i zarządzania oświatą. W związku z powyższym podjęto się przedstawienia istoty promocji oraz prezentacji wybranych narzędzi promocji, które mogą być efektywnie wykorzystane przez osoby odpowiedzialne za organizację i zarządzanie oświatą. W pracy przyjęto następującą hipotezę badawczą: z perspektywy zarządzających promocja powinna stanowić sekwencję działań systemowych (na realizację których zapewnione są odpowiednie zasoby), celowych i zaplanowanych, opartych na odpowiednio dobranych metodach i formach skierowanych do zdefiniowanych odbiorców (zarówno do klientów wewnętrznych, jak i zewnętrznych). 
Walorem aplikacyjnym niniejszego opracowania jest uporządkowanie i wskazanie komponentów ważnych przy konstruowaniu planu promocji szkoły. Autorka ma nadzieję, iż opracowanie ułatwi pracę szkolnym zespołom ds. promocji, na czele których staje dyrektor - szczególnie ten, który rozpoczyna swoją pracę na stanowisku kierowniczym. Podjęcie się obowiązków organizacyjno-zarządczych w jednostce oświatowej stanowi wyraz przedsiębiorczości dyrekcji. Jej odzwierciedleniem jest nie tylko jakość wykonywanej pracy ocenianej przez różne grupy interesariuszy, ale także pożądany wizerunek szkoły w szeroko rozumianym środowisku. Wizerunek ten należy systematycznie budować według ściśle zdefiniowanej strategii wynikającej z wizji/misji, a ujętej w koncepcji pracy szkoły.

Niezwykle ważne jest zastosowanie instrumentów marketingowych w szkolnictwie. W pracy starano się wykazać, iż promocja szkoły staje się coraz ważniejszym elementem w walce konkurencyjnej na rynku usług edukacyjnych. Kadra odpowiedzialna za organizację i zarzadzanie w oświacie - w szczególności osoby na stanowiskach kierowniczych musi nabywać, a także ciągle uaktualniać kompetencje z zakresu specyfiki marketingowej koncepcji zarządzania w organizacjach niekomercyjnych.

W związku z przyjętymi celami pracy wykorzystano metodę studiów literaturowych (badanie typu desk research), analizę typu case study oraz benchmarking.

\section{Promocja jako proces}

Elementy marketingu mix dla usług edukacyjnych stanowią w szczególności: produkt (zakres świadczonych usług, jakość pakietu usług, marka), cena, dystrybucja (lokalizacja placówki edukacyjnej), promocja, personel (pracownicy placówki edukacyjnej - dydaktyczni i niedydaktyczni, obsługa klienta), polityka, opinia publiczna (dziennikarze, liderzy opinii), świadectwo materialne (miejsce świadczenia usługi, materialne atrybuty usługi), proces (unikatowe, a jednocześnie standaryzowane świadczenie usługi, np. wynikające z organizacji pracy) (Smoleń-Jajeśnica, 2017). Promocja stanowi więc jeden z dziewięciu kluczowych elementów marketingu mix dla usług edukacyjnych, który odnosi się do specyficznego oddziaływania między podażową, a popytową stroną rynku.

Literatura przedmiotu jest bogata w definicje odnoszące się do tego, jak należy rozumieć promocję. Przegląd stosowanych przez licznych autorów definicji pozwala zauważyć, że prawidłowa promocja jest nierozerwalnie związana z procesem komunikowania się z otoczeniem, w celu budowania pożądanego wizerunku organizacji i skutecznego przekonywania odbiorców informacji (stanowiących w szczególności grupy docelowe) do nabywania oferowanych przez organizację produktów/usług. Ponadto $\mathrm{w}$ procesie zarządzania zmianą $\mathrm{w}$ turbulentnym otoczeniu jest to narzędzie służące do budowania pożądanego, pozytywnego wizerunku organizacji w otoczeniu - szczególnie wśród klientów - oraz element ważnego mechanizmu sprzężenia zwrotnego pozwalającego na uzyskanie informacji z rynku m.in. na temat popytu. Promocja stanowi w gospodarce rynkowej cenny instrument wykorzystania opisywanej w literaturze z zarządzania strategii judo, gdyż prawidłowo prowadzona pozwala na wykorzystanie szans pojawiających się np. w momencie zidentyfikowania potrzeb niezaspokojonej dotąd niszy rynkowej. Niszę rynkową mogą generować w szczególności interesariusze szkoły (w szczególności potencjalni uczniowie szkoły, a także ich rodzice/opiekunowie prawni). To oni są bowiem bezpośrednimi odbiorcami oferowanych przez szkołę kompleksowych usług edukacyjno-wychowawczych. 
Promocja musi stanowić dynamiczny proces - sekwencję działań systemowych (na realizacje których zapewnione są odpowiednie zasoby), celowych i zaplanowanych, opartych na odpowiednio dobranych metodach i formach skierowanych do zdefiniowanych odbiorców (zarówno do klientów wewnętrznych, jak i zewnętrznych). Oddziałuje ona bowiem na zasadzie sprzężenia zwrotnego na różne grupy interesariuszy - szczególnie lokalnych.

\section{Cele promocji szkoły}

W literaturze przedmiotu odnoszącej się do zagadnienia kursów kwalifikacyjnych w zakresie organizacji i zarządzania oświatą zwraca się uwagę na to, iż w wyniku ukończenia kursu kandydat, chcący pełnić funkcje kierownicze, powinien nabyć kompetencje z zakresu:

- komunikacji społecznej (interpersonalnej, masowej, medialnej, grupowej, publicznej, międzykulturowej) (Michałowska, 2013; Ustawa...),

- zarządzania zespołem (zwłaszcza w odniesieniu do kształtowania warunków dla zrównoważonego rozwoju szkoły (samokształcenia i wspierania rozwoju zawodowego podległego mu zespołu pracowników dydaktycznych i administracyjnych m.in. poprzez wykorzystanie wiedzy psychologicznej) (Hajduk, 2005; Domaradzka-Grochowalska, 2015),

- delegowania uprawnień, organizowania pracy administracyjno-biurowej oraz nadzoru pedagogicznego,

- stosowania nowoczesnych rozwiązań/technik informacyjnych w zarządzaniu (Ożarek, 2007),

- interpretowania i właściwego stosowania wymogów legislacyjnych (dotyczących w szczególności prawa oświatowego, finansowego, kadrowego, zamówień publicznych, bezpieczeństwa i higieny pracy, prawa dostępu do informacji publicznej) (Kulmatycki, 2012),

- zarządzania procesem budowania systemu jakości pracy szkoły (w sposób sprawny i efektywny) (Gańko, 2006),

- zarządzania zmianą (Wojciechowski, 2014),

- tworzenia sprawnie działającej platformy współpracy z interesariuszami szkoły,

- koordynacji procesu promocji szkoły (Jaworska, 2003).

Promocja szkoły stanowi coraz istotniejsze zadanie dla każdego dyrektora i współpracującego z nim grona pedagogicznego, gdyż w dobie gospodarki wolnorynkowej, niekorzystnych procesów społecznych oraz demograficznych coraz wyraźniejsza jest walka konkurencyjna o każdego ucznia, a tym samym - o utrzymanie miejsc pracy.

Szczegółowe cele promocji szkoły można ująć w następujących kategoriach:

- budowanie świadomości marki (Gawrecki, 2008);

- kreowanie reputacji i wizerunku szkoły przyjaznej dla interesariuszy (całej społeczności uczniów, wszystkich rodziców, nauczycieli oraz społeczności - w szczególności lokalnej). Należy mieć na uwadze, iż reputacja jest ważna szczególnie wtedy, gdy liczy się jakość usługi, która gwarantowana jest w długim okresie. Kreowanie wizerunku i reputacji jest współcześnie szczególnie ważne w przypadku wystąpienia sytuacji kryzysowych (Tołwińska-Królikowska, 2015);

- wzmacnianie prestiżu (znaczenia szkoły) w opinii władz samorządowych i oświatowych (Orzechowska, 2010); 
- wzmocnienie pozycji konkurencyjnej szkoły na ciągle zmieniającym się rynku usług edukacyjnych, a tym samym zapewnienie jej rozwoju przez wskazanie odrębności szkoły (jej wizji, misji) oraz przez innowacje procesowe, produktowe, systemowe. Należy mieć na uwadze, że nawet szkoły tych samych szczebli różnią się pod względem organizacyjnym oraz programowym. Umiejętnie wyeksponowane w kampanii promocyjnej różnice mają istotny wpływ na wybór danej szkoły przez ucznia) (Kazimierowicz, 2010);

- prezentowanie osiągnięć i potencjału społeczności tworzącej szkołę - generowanie efektu synergii;

- rekrutacja pożądanego profilu uczniów/zwiększanie liczby uczniów m.in. przez budowanie lojalności i autentycznego zaangażowania emocjonalnego (Hall 2007);

- pozyskiwanie, ciągłe rozwijanie i utrzymywania najlepszych, otwartych na zmiany nauczycieli (Budzińska, Klimka, 2012);

- nawiązywanie i kontynuowanie współpracy, pozyskiwanie funduszy (m.in. ze środków UE) oraz sponsorów i pożądanych partnerów niezbędnych do realizacji wyznaczonych celów wynikających $\mathrm{z}$ istoty funkcjonowania danego typu szkoły (Buczak, 2016);

- zarządzanie relacjami dzięki kształtowaniu pozytywnych więzi emocjonalnych (opartych na zaufaniu, sympatii, wiarygodności szkoły w społeczności lokalnej - np. przez kluby absolwentów). W literaturze przedmiotu nie ma zgodności co do definicji relacji (Drapińska, 2011). Można w pewnym uproszczeniu przyjąć, iż relacje na rynku edukacyjnym stanowią więzi między stronami, będące wynikiem długotrwałego procesu, podczas którego na podstawie wielu różnych czynników obopólnie kreowana jest wartość, z której strony czerpią korzyści. Strony będą zainteresowane nawiązaniem relacji w sytuacji, gdy koszty poniesione $\mathrm{w}$ związku $\mathrm{z}$ tym procesem będą niższe niż możliwe do wygenerowania korzyści, co w efekcie powinno przełożyć się na poprawę pozycji konkurencyjnej na rynku (Maciejczuk-Tytus, 2014). Do korzyści wynikających z zarządzania relacjami należy zaliczyć: możliwość budowania pożądanej pozycji rynkowej przez ciągłe doskonalenie i coraz lepsze dopasowanie usługi edukacyjnej do wymagań klienta (dzięki zmianie i efektowi synergii wynikającemu ze wspólnego tworzenia usługi poprzez zaangażowane strony, w wyniku wzrostu otrzymanej wartości i zbudowania prestiżu w otoczeniu). Zgodnie z założeniami koncepcji High Speed Management kluczem do sukcesu jest umiejętność dostarczania klientom właściwej wiązki wartości w sposób lepszy, niż to czynią konkurenci (Hajduk, M., Hajduk, E., 2004);

- budowanie poczucia satysfakcji nabywców usług oraz niwelowanie tzw. dysonansu spowodowanego procesem decyzyjnym („zakupowym”), w celu wzmacniania przekonania o trafności dokonanego wyboru (wśród rodziców oraz partnerów szkoły).

Dysonans pozakupowy stanowi naturalny odruch myślowy u człowieka i, jak podkreśla Kotler, każdy z konsumentów doznaje przynajmniej niewielkiego dysonansu pozakupowego w przypadku każdego zakupu (Kotler, 2002a, 2002b). Konsument odczuwa dyskomfort, gdy otrzymuje z otoczenia sygnały o wadach wybranej marki oraz gdy rozważa tzw. koszt utraconych korzyści związanych z odrzuconymi wcześniej (w procesie decyzyjnym) produktami/usługami. Dysonans odnosi się do pytań: Czy na pewno nabyliśmy dobrą usługę? Czy jakość usługi spełnia określone wymagania? Czy jest adekwatna do ceny? Co by było, gdybyśmy wybrali alternatywny produkt innej firmy? Zjawisko dysonansu może być spowodowane nie tylko wątpliwościami dotyczącymi walorów odnoszących się 
do cech nabytego produktu (usługi). Może ono wynikać także z niezadowolenia z danego produktu/usługi powstającego na skutek uzyskania błędnych informacji na jego temat (Grupa, 2012).

Konkludując, skuteczny dyrektor współczesnej szkoły czy placówki oświatowej musi posiadać, ciągle uaktualniać i umiejętnie wykorzystywać wiedzę z zakresu zarządzania, w celu realizacji zadań podległej mu organizacji.

\section{Odbiorcy działań promocyjnych szkoły}

Analizując literaturę przedmiotu (a w szczególności regulacje prawne odnoszące się do wyzwań, którym musi sprostać współczesna szkoła), można zauważyć, iż autorzy podkreślają, iż partnerami szkoły są w szczególności:

- podmioty nadzorujące oraz wspierające szkołę w realizacji jej zadań statutowych (np. władze samorządowe i oświatowe),

- osoby fizyczne, prawne, inne jednostki organizacyjne reprezentujące podmioty społeczne środowiska, z którymi szkoła współpracuje na zasadzie obligatoryjności lub fakultatywności w związku z realizacją obopólnych celów (np. policja, organizacje społeczne, sądy, stacje sanitarno-epidemiologiczne),

- sponsorzy.

Warto wykonać analizę SWOT oraz analizę interesariuszy, aby lepiej zrozumieć pozycję swojej szkoły w otoczeniu, oraz siłę i zakres wpływu poszczególnych aktorów z tego otoczenia na to, jak dziś, a jak w przyszłości szkoła (zgodnie z różnymi scenariuszami) może funkcjonować.

Podsumowując, warto zauważyć, że zasadniczo wyodrębnić można dwa rodzaje działań służących promocji szkoły. Pierwszy z nich stanowi sukcesywne kształtowanie pozytywnego wizerunku szkoły przez wszystkich pracowników przez sumienne, kompetentne i uczciwe wykonywanie powierzonych obowiązków służbowych (odpowiednio do zajmowanego stanowiska). Drugi odnosi się do promocji rozumianej w wąskim tego słowa znaczeniu. Opiera się ona na podejmowaniu działań doraźnych, służących ściśle osiąganiu planowanych celów zmierzających do upowszechniania wiedzy o pracy i osiągnięciach szkoły (Murawska i in., 2013). Ten komponent związany jest także z pozyskiwaniem środków finansowych.

Wybrane instrumenty komunikacji marketingowej wykorzystywane w promocji szkoły

Narzędziami w obszarze promocji są w szczególności reklama, sprzedaż osobista, promocja sprzedaży, public relations. W celu przygotowania (w sposób prawidłowy) promocji szkoły należy w szczególności przeanalizować kwestie związane z tym:

- Jaki jest wizerunek szkoły w otoczeniu bliższym i dalszym? Z jakich przesłanek on wynika?

- Jak wygląda prezentacja oferty szkoły - jakie są mierniki jej skuteczności?

- Czy i w jaki sposób jest wykorzystywana reklama w mediach?

- Kto i w jaki sposób realizuje działania związane z public relations szkoły?

- Czy i w jaki sposób wykorzystywane są narzędzia wizualizujące szkołę, np. druki akcydensowe w korespondencji? 
- Jak odbierani jesteśmy przez różne grupy interesariuszy pod względem dydaktycznym?

- Kto jest naszym konkurentem, jakie są jego mocne i słabe strony, jaki mamy potencjał, aby wykorzystać nadarzające się okazje i możliwości w otoczeniu?

- Czy i co chcemy zmienić w naszej szkole - dlaczego to dla nas ważne?

$\mathrm{W}$ procesie związanym $\mathrm{z}$ promocją niezwykle istotne jest wykorzystywanie elementów, które związane są z kulturą organizacyjną danej jednostki edukacyjnej, gdyż to one na pierwszy rzut oka stanowią jej estetyczny wyróżnik z konkurencyjnego otoczenia.

Ważne jest opracowanie i wykorzystywanie instrumentów komunikacji marketingowej (właściwej jakości środków promocyjnych):

- materiałów identyfikacji wizualnych (logotypów, papeterii, wizytówek, plakatów, reklamówek, broszur, informatorów, ustandaryzowanych grafik na stronie internetowej, czy wizualizacji danych szkoły na znormalizowanym tzw. papierze firmowym);

- banerów z logo i nazwą szkoły;

- elementów identyfikacji graficznej, np. na odzieży (modnej, wygodnej, dobrej jakościowo), takiej jak ustandaryzowane bluzy, koszulki z logo lub/i logotypem, które będą noszone przez uczniów lub/i nauczycieli. W praktyce występują problemy z rozróżnieniem tego, czym się różni logo od logotypu. Graficzną formę przedstawienia symbolu firmy bądź marki określa się jako logo (np. ugryzione jabłko w przypadku firmy Apple). Logotyp zarezerwowany jest tylko i wyłącznie do tekstowej formy wizualnej. Terminu logo powinno się więc używać jako nazwy zbiorczej dla całego znaku, który składa się z sygnetu (symbolu graficznego) i logotypu (tekstowego przedstawienia nazwy). Potocznie jednak terminem logo określany jest sam sygnet bądź sam logotyp (Walkiewicz, 2011);

- prezentacji wykorzystującej nowoczesne rozwiązania oferowane przez technologię ICT (m.in. prezentacje multimedialne zawierające np. zabawne filmiki przygotowane przez uczniów, a przedstawiające kulturę organizacyjną danej szkoły - tzw. klimat (nie tylko jej ofertę dydaktyczno-wychowawczą, bazę sportową, wyposażenie pracowni w pomoce dydaktyczne, ale także komponenty, dzięki którym potencjalny klient na własne oczy zobaczy życie placówki. Należy więc w tych materiałach uwypuklić: sukcesy uczniów, wyniki egzaminów zewnętrznych, galerię zdjęć i filmów stanowiących interesującą kronikę. Ponadto należy wskazać na pozytywne relacje z rodzicami, absolwentami, sponsorami i innymi grupami interesariuszy - np. dokumentację elektroniczną działania koła psychologicznego/teatru/kabaretu, samorządu uczniowskiego, kół zainteresowań, różnych form wolontariatu. Współcześnie, w dobie niemalże powszechnego dostępu do Internetu, wydaje się być nieuzasadnionym przygotowywanie jako materiałów reklamowych płyt CD. Jak stwierdził P. Bogajewicz: „Internet to miejsce na ćwiczenie najlepszych technik aktorskich bez pokazywania się na scenie" (Bogajewicz, 2007: 23). Warto podkreślić, że Internet daje szansę na jednoczesne, szybkie i bezkosztowe przekazywanie różnorodnych informacji m.in. dzięki wykorzystaniu właściwie przygotowanych baz danych adresowych. Ważne w tym kontekście jest profesjonalne przygotowanie i realizowanie aktywności w sieci przez własne strony WWW, ich pożądane pozycjonowanie, prowadzenie profili w serwisach społecznościowych);

- strony internetowej obrazującej bieżącą działalność placówki, w szczególności zaś prezentującej ciekawe, nietuzinkowe informacje. Strona internetowa z racji łatwości przygotowania i w zasadzie nieograniczonego terytorialne i czasowo dostępu: 
1. powinna umożliwiać szybką i skuteczną komunikację między różnymi interesariuszami szkoły (szczególnie między uczniami, rodzicami a nauczycielami); 2. powinna być na bieżąco aktualizowana (24/7/365), gdyż jest nie tylko narzędziem promocji, ale także instrumentem informacyjnym; 3. powinna być przygotowywana z myślą, iż jest medium typu pull (Hajduk, E., Hajduk, M., 2005);

- kolorowych (niestandardowych w formie) folderów przygotowanych (najlepiej przez aktualnych uczniów) z wykorzystaniem technik typu ambient media, w których znajdą się wskazówki odnoszące się do najważniejszych informacji o danych teleadresowych szkoły, profilach kształcenia, innowacyjnych rozwiązaniach pedagogicznych, źródłach przewag nad innymi szkołami (np. w postaci laboratoriów realizowanych na terenie uczelni wyższej);

- gazetek szkolnych odnoszących się do kwestii ważnych z perspektywy zainteresowań młodzieży;

- galanterii reklamowej zwanej gadżetami (drobnych upominków: kalendarzyków, planów lekcji, naklejek i innych drobnych materiałów np. biurowych z logo szkoły, długopisów, logosmyczy, kubków, balonów);

- umów partnerskich będących wyrazem profesjonalizmu, zaangażowania i zapewnienia bezpieczeństwa obu stronom. Umowy partnerskie podnoszą prestiż współpracy;

- rekomendacji zadowolonych interesariuszy.

\section{Wydarzenia wystawiennicze jako instrument promocji szkoły}

W kontekście zbliżających się niekorzystnych zmian demograficznych coraz większego znaczenia w wachlarzu stosowanych instrumentów promocji nabierają (ze względu na swoje szczególne cechy) wydarzenia wystawiennicze. Targi edukacyjne pozwalają na równoczesną realizację celów zarówno wystawcom, jak i zwiedzającym. Dlatego stanowią one - w opinii M. Gębarowskiego - oddzielny instrument, komplementarny wobec wszystkich elementów kompozycji promocyjnej, a zarazem selektywnie wykorzystujący poszczególne formy komunikacji (Gębarowski, 2010). Wydaje się, że podobną interpretację można odnieść także do tzw. dni otwartych przygotowywanych w szkołach.

Do etapów projektowania oraz realizowania procesu wystąpienia targowego należy podjęcie decyzji w obszarach takich, jak (Gębarowski, 2012):

- wybór targów, biorąc pod uwagę kryterium zasięgu w dwojakim ujęciu:

- ilościowym - odnoszącym się do frekwencji publiczności targowej oraz wystawców,

- jakościowym - wyznaczanym przez profil odwiedzających. Na tym etapie należy przeanalizować także: wysokość opłat z tytułu uczestnictwa w targach, harmonogram imprez towarzyszących targom, wizerunek organizatora, zainteresowanie mediów wcześniejszą edycją, własne doświadczenia, obecność instytucji, z którymi wystawca bezpośrednio konkuruje;

- ustalenie budżetu wystąpienia targowego;

- dobór członków zespołu do reprezentacji na targach - powinni oni być: 1. tolerancyjni i życzliwi, gdyż uczestnicy targów nie zawsze zachowują się kulturalnie, 2. cierpliwi w udzielaniu odpowiedzi nawet na banalne pytania, 3. pozbawieni „wszystkowiedzącego, wywyższającego się” tonu, 4. dopasowani pod względem właściwego kodowania - w szczególności jakości używanego języka (żargonu wykorzystywanego przez młodzież); 
- przygotowanie materiałów reklamowych;

- uczestnictwo w targach, podczas których warto wspierać się: modelami, makietami, planszami, plakatami, filmami lub prezentacjami wyświetlanymi na monitorach. Interesującym pomysłem jest wykorzystanie infokiosków (kiosków multimedialnych) z ekranami dotykowymi. W celu nadania dynamizmu warto włączyć dodatkowe eventy, takie jak konkursy, loterie, specjalne pokazy (np. możliwości specjalistycznego oprogramowania używanego w szkole);

- ocena wystąpienia targowego.

Ważnym czynnikiem skutecznego oddziaływania na młodzież jest angażowanie do zespołu prezentującego ofertę swojej szkoły na targach nie tylko uczniów, ale także nauczycieli, którzy w sposób świadomy wykorzystują otwarty styl komunikacji. Jakość pracy zespołu uczestniczącego $\mathrm{w}$ targach jest zasadniczym czynnikiem sukcesu działalności wystawienniczej - szczególnie w przypadku najczęściej stosowanych na targach (ze względów ekonomicznych i pragmatycznych) standardowych systemów zabudowy oktagonalnej. Należy pamiętać, że etap wieńczący wystąpienie wystawiennicze stanowią tzw. działania follow-up. Mają one na celu:

- rozwijanie kontaktów nawiązanych na stoisku,

- uporządkowanie i przeanalizowanie pozyskanych (m.in. od konkurencji) materiałów informacyjno-reklamowych (w szczególności kwestionariuszy ankiet odnoszących się do oczekiwań absolwentów gimnazjów/szkół podstawowych oraz wizerunku naszej szkoły),

- ocenę rezultatów aktywności wystawienniczej (liczba rozdawanych materiałów reklamowych, przeprowadzonych rozmów na stoisku, zebranych ankiet, osób, które wzięły udział w organizowanych konkursach itp.).

\section{Zakończenie}

Przygotowanie skutecznego programu działań promocyjnych szkoły związane jest z podjęciem szeregu racjonalnych decyzji, które sprowadzają się zasadniczo do udzielenia odpowiedzi na następujące pytania (Wschód Biznesu 2, 2017: 12):

- „DLA KOGO? Czyli kto jest odbiorcą naszych działań promocyjnych?

- CO? Cel promocji, czyli to jaki produkt, usługę, informację chcemy wypromować?

- JAK? Poprzez zastosowanie jakich form i środków?

- ZA JAKIE PIENIĄDZE? - ustalamy optymalny budżet”.

Konkludując, należy stwierdzić, iż zarys celów strategicznych oraz operacyjnych planu promocji szkoły (w świetle doświadczeń zarówno badaczy, jak i realizatorów zagadnień związanych z promocją instytucji oświatowych) powinien uwzględniać w szczególności indywidualny charakter tej organizacji oraz:

- kształtowanie pozytywnego wizerunku szkoły w środowisku lokalnym (mając na uwadze integrację z tym środowiskiem),

- współtworzenie szkolnej witryny internetowej oraz aktualizowanie stron/postów mediów społecznościowych (typu: Facebook, Instagram, Snapchat, YouTube, Twitter),

- zarządzanie oczekiwaniami klientów, m.in. przez promowanie osiągnięć szkoły i jej aktualnych oraz byłych uczniów,

- prezentowanie zmieniającej się oferty edukacyjnej szkoły jako odpowiedzi na zmieniające się potrzeby różnych zainteresowanych stron, 
- wielopłaszczyznową współpracę ze środowiskiem lokalnym (obejmującą także pozyskiwanie funduszy),

- uczestnictwo w uroczystościach ważnych dla społeczności szkolnej/lokalnej,

- współpracę obligatoryjną i fakultatywną z instytucjami, placówkami i innymi interesariuszami (m.in w ramach organizacji i prowadzenia kampanii społecznych) (Herbuś, 2016),

- współpracę z mediami,

- współorganizowanie imprez o charakterze otwartym,

- przygotowywanie wydawnictw reklamowych dotyczących szkoły,

- uczestnictwo szkoły w różnego typu projektach edukacyjnych - szczególnie tych stanowiących innowacyjne rozwiązania,

- inicjowanie działalności innowacyjnej w różnych obszarach życia szkoły.

Należy pamiętać, iż po realizacji programu promocji szkoły niezbędna jest ocena skuteczności funkcjonowania programu. Nie będzie ona łatwa ze względu na procesowe podejście $\mathrm{w}$ marketingu relacyjnym. W tym kontekście podkreśla się znaczenie monitorowania procesów od momentu inicjowania zadań według podwójnej pętli uczenia się. Z pojedynczą pętlą uczenia mamy do czynienia najczęściej w przypadku działań rutynowych. Określone w planach zadania są w tym przypadku wykonywane (powinna występować zgodność między planem a rzeczywistością, może jednak zaistnieć sytuacja, gdy dokonuje się naprawy niezgodności przez działania korekcyjne). Podwójna pętla uczenia się występuje wtedy, gdy uczestnicy organizacji zadają sobie pytanie o powody, dla których pewne rzeczy są wykonywane inaczej, niż to przewiduje plan. Podwójna pętla uczenia się wiąże się z dużym zaangażowaniem w zrozumienie, dlaczego występuje niezgodność między planem a rzeczywistością. Nie podejmuje się tutaj działań korekcyjnych, gdyż są one nieskuteczne - w kontekście doskonalenia procesu. Podejmuje się więc działania mające na celu zrewidowanie, czy wręcz zakwestionowanie obowiązujących praktyk. Ich konsekwencją jest możliwość odejścia od strategii, którą dotychczas stosowała organizacja (Argyris, Schön, 1974). W tym przypadku niezgodność jest korygowana dzięki uzyskaniu wiedzy o tym, jaka jest faktyczna jej przyczyna, a nie jaki jest jej objaw. Prowadzi więc do podjęcia działań zapobiegawczych - wpływa na proces planowania. Podwójna pętla uczenia się tworzy mechanizm typu Poke-Yoke.

Literatura

Referencess

Argyris, M., Schön, D. (1974). Theory in Practice. Increasing professional effectiveness. San Francisco: Jossey-Bass.

Bartnik, M. (2007). Skuteczna reklama. Jak reklamować, żeby sprzedać. Warszawa: Wydawnictwo Flashbook.

Buczak, A. (2016). Nauka obroni się sama...? Czyli współczesny marketing w szkolnictwie. Prace Naukowe Wyższej Szkoły Zarządzania i Przedsiębiorczości z siedziba w Wałbrzychu, 37(1).

Budzińska, G., Klimka, M. (2012). Coaching w procesie uczenia się przez całe życie. CLLL. Pozyskano z: http://www.adam-europe.eu/prj/6832/prd/8/5/POLSKA\%20Coaching\%20for\%20Career\%20 Learning.pdf

Domaradzka-Grochowalska, Z. (2015). Wspomaganie szkół i przedszkoli. Coaching, mentoring i inne formy pracy. Materiały szkoleniowe, Warszawa: ORE. Pozyskano z: http: //www.coachfederation. org/intcoachingweek/about-coaching/ file:///C:/Documents\%20and\%20Settings/TEST/Moje\%20 
dokumenty/Downloads/Wspomaganie_szkol_i_przedszkoli_coaching_mentoring_i_inne_formy_pracy.pdf

Drapińska, A. (2011). Zarządzanie relacjami na rynku usług edukacyjnych szkół wyższych. Warszawa: PWN.

Gańko, T. (2006). Wspomaganie szkół i placówek oświatowych w zakresie budowania jakości w edukacji. Meritum, 2(2), 35-38.

Gawrecki, L. (2008). Promowanie szkoły jako instytucji świadczącej usługi edukacyjne. Dyrektor Szkoły. Miesięcznik Kierowniczej Kadry Oświatowej, 6, 9-11.

Grupa, R. (2012). Satysfakcja pozakupowa i dysonans pozakupowy jako czynniki determinujące reakcje konsumenckie. Społeczeństwo i Edukacja, Międzynarodowe Studia Humanistyczne, 1, 483-494.

Gębarowski, M. (2010). Współczesne targi. Skuteczne narzędzie komunikacji marketingowej. Gdańsk: Regan Press.

Gębarowski, M. (2012). Targi edukacyjne jako forma promocji szkół wyższych. Prace Instytutu Lotnictwa, $4(225)$.

Hajduk, M., Hajduk, E. (2004). Analiza wybranych modeli konkurencji kluczem do kształtowania przewagi polskich przedsiębiorstw na rynkach europejskich. W: J. Brdulak, M. Kulikowski (red.), Przedsiębiorczość stymulatorem rozwoju gospodarczego. Warszawa: Szkoła Główna Handlowa.

Hajduk, M. (2005). Wpływ zasobów ludzkich na konkurencyjność przedsiębiorstwa. Kijów: Ministerstwo Edukacji Narodowej Ukrainy.

Hajduk, E., Hajduk, M. (2005). Wybrane aspekty związane z wykorzystaniem Internetu w biznesie. W: A. Szewczyk (red.), Komputer - przyjaciel czy wróg?. Szczecin: Uniwersytet Szczeciński, Wydział Nauk Ekonomicznych i Zarządzania, Instytut Informatyki w Zarządzaniu, Wydawnictwo Printshop, 47-68.

Hall, H. (2007). Marketing w szkolnictwie. Warszawa: Wydawnictwo ABC Wolters Kluver Business.

Herbuś, I. (2016). Działania reklamowe - od komercji do kampanii społecznych. Zeszyty Naukowe Politechniki Częstochowskiej - Zarządzanie, 22, 93-100.

Jaworska, E. (2003). Public relations w Zespole Szkół Medycznych w Łańcucie. Dyrektor Szkoły. Miesięcznik Kierowniczej Kadry Oświatowej, 4, 10-11.

Kazimierowicz, M. (2010). „Promocyjna sprzedaż” szkoły. Nowa Szkoła, 9, 23-29.

Kotler, P. (2002a). Marketing, Management. Millenium Edition, Custom Edition for University of Phoenix, USA: Pearson Custom Publishing.

Kotler, P. (2002b). Marketing. Podręcznik europejski. Warszawa: Polskie Wydawnictwo Ekonomiczne.

Kulmatycki, A. (2012). Szkoła a media. Część I. Specyfika mediów: metody pracy i oczekiwania. Dyrektor Szkoły. Miesięcznik Kierowniczej Kadry Oświatowej, 7.

Maciejczuk-Tytus, U. (2014). Kontakt - pseudorelacja - relacja w usługach edukacyjnych. Ekonomika i Organizacja Przedsiębiorstwa, 11(778), 24-31.

Michałowska, D.A. (2013). Komunikacja społeczna a komunikacja interpersonalna. Poznań. Pozyskano z: https://repozytorium.amu.edu.pl/bitstream/10593/6241/1/Komunikacja\%20spo\%C5\%82eczna\%20a\%20komunikacja\%20interpersonalna.pdf

Orzechowska, L. (2010). Ku mądrej i atrakcyjnej szkole. Dyrektor Szkoły. Miesięcznik Kierowniczej Kadry Oświatowej, 12, 52-53.

Ożarek, G. (2007). Zarządzanie szkołą w społeczeństwie informatycznym. Meritum, 4(7), 18-23.

Pomianowska, M., Szczepkowska, K. (2013). Jakiego nauczyciela potrzebujemy, czyli czas rekrutacji. Dyrektor Szkoły. Miesięcznik Kierowniczej Kadry Oświatowej, 6, 45.

Sieńkowska, E. (2013). Do nastolatka przemów inteligentnie!, Marketing w praktyce, 2(180), 50-51.

Smoleń-Jajeśnica, Z. (2017). Metody i formy promocji szkoły. Materiały ze szkoleniowej Rady Pedagogicznej, ZSG w Krakowie. Pozyskano z: http://www.zsg1.pl/images/pliki/plikinauczyciele/ mifpsz.pdf

Tołwińska-Królikowska, E. (2015). Szkoła otwarta, czyli jaka?. Dyrektor Szkoły. Miesięcznik Kierowniczej Kadry Oświatowej, 10. 
Walkiewicz, A. (2011). Logotyp - czym się różni od logo. Pozyskano z: http://jaksiepromowac. $\mathrm{pl} / 2011 / 08 / 31 /$ logotyp-czym-rozni-sie-od-loga/

Wojciechowski, P. (2014). Design thinking w edukacji. Marketing $w$ Praktyce, 33.

Murawska, B., Szlom, A., Florencka, Z., Filipkowski, K., Czermak, S. (2013). Plan promocji Zespołu Szkół nr 6 na rok 2013/2014. Pozyskano z: http://www.jagiellonka.plock.pl/pdf/zespol/plan_prom_zs_6. pdf

Ustawa z dnia 26 stycznia 1984 - Prawo prasowe. Dz.U. 1984 r. nr 5, poz. 24 ze zm.

Wschód Biznesu 2 (2017, 2 sierpnia). Skuteczny plan promocji. Pozyskano z: https://www.parp.gov.pl/ files/74/517/20358.pdf

Marzena Hajduk-Stelmachowicz, dr, Politechnika Rzeszowska, Wydział Zarządzania, Katedra Ekonomii. Doktor nauk ekonomicznych, adiunkt w Katedrze Ekonomii Wydziału Zarządzania Politechniki Rzeszowskiej. Czynny nauczyciel dyplomowany. Specjalizuje się w problematyce przedsiębiorczości, implementacji metod i technik zarządzania (zarówno na poziomie zarządzania strategicznego, jak i operacyjnego) w przedsiębiorstwach oraz jednostkach administracji publicznej. Jest autorką kilkudziesięciu publikacji dotyczących rozwoju regionalnego i lokalnego, jakości, ekoinnowacji, zarządzania energią, przedsiębiorczości. Inicjowała i koordynowała projekty wdrożenia innowacyjnych systemów zarządzania w przedsiębiorstwach. Była członkiem Panelu Celów Strategicznych do spraw kreowania kultury innowacyjnej mieszkańców regionu w ramach wdrażania Regionalnej Strategii Rozwoju województwa podkarpackiego.

Marzena Hajduk-Stelmachowicz, PhD, assistant professor in the Department of Economics, Faculty of Management, Rzeszow University of Technology. She is also a chartered (diploma/certified) teacher. She specialises in methods and techniques implementation in companies and public administration institutions on strategic and operational level. The author of several dozen publications related to ecoinnovations, energy management, integrated management systems, entrepreneurship, knowledge-based economy, as well as local and regional development and education. She was an initiator and coordinator of many innovative implementation projects in companies, public institutions and Podkarpackie Voivodeship.

ORCID: https://orcid.org/0000-0003-4945-7207

Adres/Address:
Politechnika Rzeszowska
Wydział Zarządzania
Katedra Ekonomii
al. Powstańców Warszawy 12
35-959, Rzeszów, Polska
e-mail: marzenah@prz.edu.pl
Artykuł sfinansowano ze środków DS Katedry Ekonomii Politechniki Rzeszowskiej. 